\title{
Achillea goniocephala Extract Loaded into Nanochitosan: In Vitro Cytotoxic and Antioxidant Activity
}

\author{
Duygu Taskin $^{1}$, Murat Dogan ${ }^{\circledR}$, Mizgin Ermanoglu ${ }^{3}$, Turan Arabaci ${ }^{4}$ \\ ${ }^{1}$ Department of Analytical Chemistry, Faculty of Pharmacy, University of Health Sciences, Istanbul, Turkey. \\ ${ }^{2}$ Department of Pharmaceutical Biotechnology, Faculty of Pharmacy, University of Sivas Cumhuriyet, Sivas, Turkey. \\ ${ }^{3}$ Department of Pharmacognosy, Faculty of Pharmacy, Marmara University, Istanbul, Turkey. \\ ${ }^{4}$ Department of Pharmaceutical Botany, Faculty of Pharmacy, Inonu University, Malatya, Turkey. \\ Correspondence Author: Duygu Taskin \\ E-mail: duygu.taskin@sbu.edu.tr
}

Received: $16.07 .2021 \quad$ Accepted: 23.08 .2021

\begin{abstract}
Introduction: The present study aimed to prepare Achillea goniocephala chloroform extract and evaluate antioxidant and cytotoxic effects. Then, the nanoparticles (NPs) were synthesized on the most efficient extracts and the biological activities of the free forms of the extracts were compared with the NPs forms.

Methods: Antioxidant capacities of 14 extracts (A-N) prepared using column chromatography were determined by FRAP, DPPH and CUPRAC methods. Again, the cytotoxic activities of all fractions were evaluated on MCF-7 and HT-29 cell lines using the XTT cell viability assay. Chitosantripolyphosphate (TPP) NPs of the extracts with the most active biological properties were formed using the ionic gelation method.

Results: The particle size of the NPs synthesized from the two most efficient extracts was found to be between 274.12 and $296.25 \mathrm{~nm}$. The extract-encapsulation and loading-efficiency of the most active NPs were found $77.6 \pm 0.04 \%$ and $7.76 \pm 0.01 \%$ for the $F$ extract and $10.2 \pm 0.02$ and $1.39 \pm 0.07 \%$ for the $H$ extract, respectively.

Conclusions: While antioxidant activity results of chitosan NPs were close to unencapsulated extracts, cytotoxic activity results were found to be better than unencapsulated extracts. Based on these results, it is thought that it would be more effective to use the encapsulated forms of A. goniocephala instead of the raw extract of the plant in the treatment.

Keywords: Nanoparticles, Cytotoxicity, Antioxidant, Chitosan, Encapsulation efficiency
\end{abstract}

\section{INTRODUCTION}

Cancer is known as the formation of undesired tissues by uncontrolled division and proliferation of cells in the organism. There are many factors in the epidemiology of the disease, such as lifestyle and unhealthy diet, stress, radiation, and hereditary factors (1). Recently, natural compounds of plant origin, called phytochemicals, have attracted the attention of researchers in the field of pharmacy and medicine worldwide due to their highly important bioactive properties. Nowadays, studies on phytochemicals are performed in the treatment of various diseases (2). Achillea species have proven to have analgesic and anti-inflammatory, erythrocyte, and leukocyte preservative, antispasmodic (3) antioxidant and antimicrobial (4) anthelmintic, antiallergic, cholagogue, antibacterial (5) antiulcer, hepatoprotective and anxiolytic (6) effects. In addition, sesquiterpene lactones, alkaloids (senecio), esters (pyrethrins); Saponosides and coumarins have also been identified in this family. Due to the compounds, they contain, most of the Achillea plants are used in pharmacy, food industry and other industrial areas due to their latex (7). A.goniocephala Boiss. \& Balansa (A. goniocephala) is an endemic plant and when looking at the literature, there are only two studies on this species and these studies are also related to essential oil analysis. In a study, the essential oil of $A$. goniocephala was analyzed by GC/MS. Camphor and 1,8-cineole were found to be the main ingredients (8). In another study, the essential oil of this plant was analysed and high amount endo-borneol, eucalyptol and camphor were found (9).

With some new nanotechnologies such as encapsulation, preservation of active substances, reduction of activity loss and increasing bioavailability have been proven in recent years (10). The difficulties in converting the phytochemicals contained in plants into drugs are known due to reasons such as low solubility, stability, and bioavailability. Thanks to the nanostructures formed because of adding plant extracts to the nanoparticles (NPs), it has been revealed that the stability and especially the biological activities of the phytochemicals 
in the plant are increased (11). Therefore, the application of nanotechnology to plant extracts can be considered a good strategy for herbal medicines, as it provides many features such as improving pharmacological activity and especially protection from toxicity. Chitosan, which is the most used and non-toxic polymer among the coating materials used in encapsulation, shows a good encapsulation feature. Chitosan is biodegradable, biocompatible, antibacterial, and non-toxic, and besides these properties, it is an interesting material with its abundance and cheapness. For this reason, it is used in many areas such as medicine, food, pharmacy, cosmetics, textile, agriculture, and the removal of environmental pollutants from wastewater. Due to its unique properties, chitosan is widely used in drug delivery systems (12).

In this study, antioxidant, and cytotoxic activities of 14 fractions obtained using column chromatography from $A$. goniocephala chloroform extract, which was found to have a stronger effect than methanol extract in MCF-7 cell line, were evaluated. Then, NPs were prepared with two most active fractions by combining with chitosan. Thus, the biological activities of the pure forms of the extract/fractions with the biological activities of the NP forms were compared. No study has been found in the literature on the antioxidant and cytotoxic activity of the A.goniocephala. In addition, plant extract loaded NP synthesis and characterization study was carried out by us for the first time.

\section{METHODS}

\subsection{Materials}

The specimens of $A$. goniocephala were collected from field studies and determined by Prof. Dr Turan Arabacı. A voucher specimen (T.Arabacı 2957) was deposited at the herbarium of the Faculty of Pharmacy, Inönü University, Department of Pharmaceutical Botany for future reference. MCF-7 human breast cancer cells, and HT-29 human colorectal adenocarcinoma cells were obtained from the American Type Culture Collection (ATCC). Dulbecco's modified Eagle's medium (DMEM) (ATCC, USA), phosphate buffer saline (PBS), and fetal bovine serum (FBS) were purchased from PAA Ltd. (France). Chitosan (400 kDa, DD 87) were obtained from Fluka. L-glutamine-penicillin-streptomycin solution were purchased from Sigma-Aldrich. XTT reagent (2,3-bis-(2-methoxy-4nitro-5-sulfophenyl)-2H-tetrazolium-5-carboxanilide) was purchased from Roche Diagnostic.

\subsection{Extraction procedures}

The aerial parts of the plant were dried in the shade $\left(25^{\circ} \mathrm{C}\right)$ and ground to a fine powder in a mechanic grinder (Renas, RBT1250). The powdered samples were extracted with organic solvents (methanol, and chloroform) using the maceration method until colourless. The organic phase was evaporated to dryness under decreased pressure. All extracts were maintained at $4^{\circ} \mathrm{C}$ for future analysis. The cytotoxic activities of chloroform $\left(\mathrm{IC}_{50}=0.019 \mathrm{mg} / \mathrm{mL}\right)$ and methanol
$\left(\mathrm{IC}_{50}=20.391 \mathrm{mg} / \mathrm{mL}\right.$ ) extracts were assessed on the MCF-7 cell line, and it was observed that the chloroform extract was more potent against MCF-7 than methanol extract. In this study, column chromatography was performed to separate the possible effective compounds contained in the effective chloroform extract according to its polarity. The chloroform sub-extract $(7 \mathrm{~g}$ ) was inserted to a silica gel column and eluted with toluene, petroleum ether and methanol mixture of increasing polarity of petroleum ether $(100 \%, 1500 \mathrm{~mL})$, petroleum ether /chloroform (75:25, $1500 \mathrm{~mL})$, petroleum ether /chloroform $(1: 1,1500 \mathrm{~mL})$, chloroform (100\%, 1500 $\mathrm{mL})$, chloroform/methanol (75:25, $1500 \mathrm{~mL})$, chloroform/ methanol (1:1, $1500 \mathrm{~mL})$, chloroform/methanol (25:75, $1500 \mathrm{~mL})$, and methanol $(100 \%, 1000 \mathrm{~mL}$ ) to obtain fourteen fractions.

\subsection{Antioxidant assays}

Plant samples were tested with Ferric Reducing Antioxidant Power (FRAP) assay, where an increase in plant extracts' absorbance shows increase in the reducing power of the extracts (13). The FRAP results were expressed as $\mathrm{mM} \mathrm{Fe}^{2+}$ / mg extract. 2,2-diphenyl-1-picryhydrazyl (DPPH) radical scavenging capacity of the extracts was evaluated the experimental protocol found in the literature (14). Results are expressed as $I C_{50}$ values $(\mathrm{mg} / \mathrm{mL})$. In Cupric Reducing Antioxidant Capacity (CUPRAC) assay, $60 \mu \mathrm{L}$ each of copper (II) solution, neocuproin solution and ammonium acetate buffer ( $1 \mathrm{M}$ ) were mixed. $10 \mu \mathrm{L}$ ethanol and $60 \mu \mathrm{L}$ of extract were added and shake the solution. The solutions were kept in room conditions with their mouth closed for 60 minutes. At the end of this period, absorbance values at $450 \mathrm{~nm}$ were measured against the reference solution that does not contain a sample (15). CUPRAC values were given as $\mathrm{mM}$ TroloxE/mg extract.

\subsection{Cell culture conditions}

Cell culture studies were performed using modified method of (16). Cytotoxicity of the extracts was measured by the XTT assay, using HT-29 and MCF -7 cells. Cells were cultured in medium glucose DMEM with $10 \% \mathrm{FBS}, 1 \%$ L-glutamine, $100 \mathrm{IU} / \mathrm{mL}$ penicillin and $10 \mathrm{mg} / \mathrm{mL}$ streptomycin in $25 \mathrm{~cm}^{2}$ polystyrene flasks. The cells were maintained at $37^{\circ} \mathrm{C}$ within $5 \% \mathrm{CO}_{2}$ humidified atmosphere and were passaged when they had reached $80-90 \%$ confluence. Cells were seeded at $10 \times 10^{3}$ cells each well in 96-well plates containing DMEM $(100 \mu \mathrm{L})$ containing $10 \% \mathrm{FBS}$ and incubated overnight. The 14 extracts were dissolved in $20 \mu \mathrm{L}$ dimethyl sulfoxide (DMSO) and extracts with concentration $500 \mu \mathrm{g} / \mathrm{mL}$ were suspended with DMEM medium and extracts at the concentration of 50 $\mu \mathrm{g} / \mathrm{mL}$ per well were put in the 96 -well plates. In addition, the equal amount of DMSO were inserted in the positive control. Incubation of the cells was continued for $24 \mathrm{~h}$. Then, the medium was removed, and wells were washed with PBS. To determine cell viability, $100 \mu \mathrm{L}$ of transparent (colourless) DMEM and $50 \mu \mathrm{L}$ of XTT labelling solution were added to wells and the cells were incubated for $4 \mathrm{~h}$. Microplate (ELISA) 
reader was used to measure the absorbance of XTT-formazan at $450 \mathrm{~nm}$ against the control. Cell viability of extracts were calculated compared to control (100\% of viability). After the XTT results were evaluated, NPs of the two extracts showing the highest cytotoxicity in MCF-7 and HT-29 cells were prepared. NPs containing different amounts plant extract were applied to the cells separately, and the differences between their cytotoxic effects were evaluated by calculating the $I C_{50}$ values. To calculate the $I C_{50}$ value, samples and NPS containing $12.5,25,50$, and $100 \mu \mathrm{g}$ amount of plant extracts were treated with the cells.

\subsection{Preparation of chitosan NPs containing chloroform extract}

NPs were prepared using ionic gelation method as stated (17). Briefly, medium molecular weight chitosan solutions at a concentration $(0.25 \% \mathrm{w} / \mathrm{v})$ were prepared using glacial acetic acid $(0.05 \% \mathrm{v} / \mathrm{v})$ as a solvent. The chitosan dissolution process was performed via a magnetic stirrer. TPP solution $(0.25 \% \mathrm{w} / \mathrm{v})$ including extract dropped into chitosan solution under predetermined stirring condition. After the stirring period, NPs were centrifugated at $10.000 \times \mathrm{xg}$ for 30 minutes. The supernatant was removed, and particles were washed with double distilled water. This process was repeated threefold. NPs were maintained at +4 oc after lyophilisation.

\subsection{Characterization of NPs}

Zeta potential and particle size: Zeta sizer were used to measure of zeta potential and size of NPs. The samples were suspended in PBS (pH 7.4) and measured. All measurements were performed in triplicate.

Scanning electron microscope (SEM): Sample of NP was inserted in metal grids with double-sided adhesive tape, coated with a gold layer under 0.1 torr at room temperature. The morphological properties of NPs were evaluated using SEM (Carl Zeis-Evo 40, Germany) (18).

\subsection{Measurement of EE and LC}

Ultraviolet visible spectrophotometer was used to measure the encapsulation efficiency (EE \%) and loading capacity (LC $\%)$ of the extract in NPs. A standard calibration curve of the extract was established at $340 \mathrm{~nm}$. The amount of extract in the supernatant was calculated from the line equation obtained from this curve. The following equations were used to determine the encapsulation efficiency and loading capacity of the particles.

$$
\begin{aligned}
& \operatorname{EE~}(\%)=\frac{m_{0}-m_{s}}{m_{0}} \times 100 \\
& \operatorname{LC~}(\%)=\frac{m_{0}-m_{s}}{w_{n p}} \times 100
\end{aligned}
$$

where, mo is the initial mass of natural extracts and ms mass of natural extracts in the supernatant and wnp = total weight of the naturally obtained extract of NPs (19). All measurements were performed in triplicate and were reported as mean \pm SD $(n=3)$.

Total phenolic contents in the extracts and NPs were determined by Folin-Ciocalteu colorimetric method. The percentage of the encapsulated extract into chitosan NP was also determined by using a total phenolic assay according to the following equation (20).

$$
\mathrm{EE}(\%)=\frac{\text { Actual phenolic of the extract entrapped in NPs }}{\text { total phenolic of initial extract }} \times 100
$$

\subsection{Statistical analysis}

All experiments were performed in triplicate. All data from the study were given as the mean \pm SD and analysed using Graphpad Prism 5. Statistical differences between the study groups were analysed using a two-way analysis of variance (ANOVA) followed by Tukey's multiple comparison test. Mean values were considered statistically significant if $p<0.05$.

\section{RESULTS}

\subsection{Antioxidant activity}

The DPPH radical scavenging activities of the extracts were determined using DPPH method. The antioxidant activities of the extracts and ascorbic acid used as a standard were evaluated by comparing their $\mathrm{IC}_{50}$ values. $\mathrm{H}$ extract had stronger DPPH radical scavenging potential than the other extracts. The Copper (II) ion-reducing antioxidant capacity of the extracts was evaluated by the CUPRAC method. When CUPRAC results were compared, it was determined that the J, F G and $\mathrm{H}$ extracts exhibited the strongest copper (II) ion-reducing antioxidant capacity. The iron (III) ion reducing power of plants is very important in evaluating their antioxidant potential. The iron reduction power is based on the reduction of the herbal extract $\mathrm{Fe}^{3+}$ to $\mathrm{Fe}^{2+}$ and measured spectrometrically at $593 \mathrm{~nm}$. In this method, high absorbance indicates high iron reduction potential. In this study, the antioxidant power of iron (III) ion reduction of different extracts obtained from the plant was examined comparatively. It was determined that $\mathrm{G}$ extract and F extract had stronger iron (III) ion reducing power than other extracts. All the extracts were found to have lower FRAP values than BHT compound (Table 1). 
Table 1. Antioxidant capacity results of the fractions, references and nanocapsules

\begin{tabular}{|c|c|c|c|}
\hline $\begin{array}{l}\text { Extracts/ } \\
\text { compound }\end{array}$ & $\begin{array}{l}\text { DPPH } \\
\left.\text { (IC }{ }_{50}: \mathrm{mg} / \mathrm{mL}\right)\end{array}$ & $\begin{array}{l}\text { CUPRAC } \\
\text { (mM trolox } \\
\text { /mg extract) }\end{array}$ & $\begin{array}{l}\text { FRAP } \\
\text { (mM FeSO } \\
\text { /mg extract) }\end{array}$ \\
\hline$A$ & $0.611 \pm 0.218^{a}$ & $0.240 \pm 0.045^{a}$ & $9.791 \pm 0.304^{a}$ \\
\hline B & $0.561 \pm 0.077^{b}$ & $0.044 \pm 0.015^{b}$ & $9.750 \pm 0.181^{b, a}$ \\
\hline C & $1.032 \pm 0.224^{c}$ & $0.306 \pm 0.008^{c}$ & $10.355 \pm 0.160^{c}$ \\
\hline D & $1.178 \pm 0.280^{d}$ & $0.116 \pm 0.038^{d}$ & $11.585 \pm 0.716^{d}$ \\
\hline$E$ & $1.536 \pm 0.356^{e}$ & $0.212 \pm 0.016^{e}$ & $10.496 \pm 0.070^{e, c}$ \\
\hline $\mathbf{F}$ & $0.895 \pm 0.062^{f}$ & $2.582 \pm 0.158^{f}$ & $11.746 \pm 0.209^{f}$ \\
\hline G & $0.809 \pm 0.101^{\mathrm{g}}$ & $2.006 \pm 0.158^{g}$ & $13.540 \pm 0.384^{\mathrm{g}}$ \\
\hline H & $0.264 \pm 0.037^{h}$ & $1.111 \pm 0.038^{h}$ & $10.879 \pm 0.152^{h}$ \\
\hline I & $1.349 \pm 0.635^{\prime}$ & $1.050 \pm 0.010^{\prime}$ & $10.980 \pm 0.244^{\mathrm{l}, \mathrm{h}}$ \\
\hline J & $1.266 \pm 0.278^{j}$ & $3.155 \pm 0.172^{j}$ & $11.565 \pm 0.218^{j}$ \\
\hline $\mathrm{K}$ & $0.890 \pm 0.289^{k}$ & $0.780 \pm 0.047^{k}$ & $10.395 \pm 0.185^{k, c}$ \\
\hline$L$ & $1.543 \pm 0.210^{\prime}$ & $0.702 \pm 0.060$ & $10.416 \pm 0.060$ \\
\hline$M$ & $2.012 \pm 0.688^{\mathrm{m}}$ & $0.664 \pm 0.095^{\mathrm{m}}$ & $10.436 \pm 0.152^{\mathrm{m}, \mathrm{l}, \mathrm{e}}$ \\
\hline $\mathrm{N}$ & $2.499 \pm 0.423^{n}$ & $0.412 \pm 0.017^{n}$ & $10.154 \pm 0.175^{n}$ \\
\hline H capsule & $1.054 \pm 0.163^{\circ}$ & $0.155 \pm 0.032^{\circ}$ & $8.780 \pm 0.740^{\circ}$ \\
\hline F capsule & $1.426 \pm 0.060^{p}$ & $0.759 \pm 0.040^{p, k}$ & $8.659 \pm 0.083^{p, o}$ \\
\hline Ascorbic acid & $0.0028 \pm 0.000^{4} r$ & & \\
\hline BHT & & $4.462 \pm 0.074^{r}$ & $21.706 \pm 0.726^{r}$ \\
\hline
\end{tabular}

All results were expressed as mean $\pm S D$ by three independent experiments; Means with different superscripts ${ }^{(a-r)}$ are significantly different, $p<0.05$.

\subsection{Characterization of chitosan NPs}

Particle size, zeta potential, polydispersity index (PDI) of NPs were evaluated and results shown in Table 2 . The size of the NPs obtained between $274.12 \pm 2.7 \mathrm{~nm}$ and $296.25 \pm 3.2 \mathrm{~nm}$. The zeta potential values of NPs were between $2.3 \pm 0.04$ $\mathrm{mV}$ and $3.0 \pm 0.03 \mathrm{mV}$. PDI values were between $0.298 \pm 0.03$ and $0.342 \pm 0.04$. These results showed that the samples were homogeneous feature without any aggregate. The morphological properties of the NPs were shown in Figure 1.

Table 2. Zeta potential, particle size, and PDI values of NPs loading with extract

\begin{tabular}{llll}
$\begin{array}{l}\text { Formulations } \\
\text { (Chitosan - TPP }\end{array}$ & Zeta potential $(\mathrm{mV}) \pm S D$ & Size $(\mathrm{nm}) \pm \mathrm{SD}$ & $\mathrm{PDI} \pm \mathrm{SD}$ \\
NPs) & & & \\
${ }^{*} \mathrm{NP1}$ & $2.3 \pm 0.04$ & $274.12 \pm 2.7$ & $0.298 \pm 0.03$ \\
${ }^{*} \mathrm{NP2}$ & $2.7 \pm 0.02$ & $280.15 \pm 3.6$ & $0.313 \pm 0.03$ \\
${ }^{*} \mathrm{NP3}$ & $3.0 \pm 0.03$ & $296.25 \pm 3.2$ & $0.342 \pm 0.04$ \\
\hline
\end{tabular}

* NP1, NP2, and NP3 containing chitosan (MW: $400 \mathrm{kD}$ ), TPP and A. goniocephala chloroform extract. Nanoparticles: NPs.
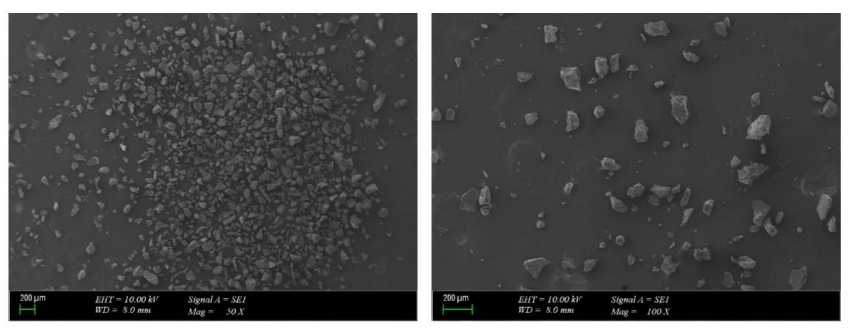

Figure 1. SEM images of chitosan nanoparticles.

\subsection{Percentage of Encapsulation efficiency from $A$. goniocephala extracts-chitosan NP}

Encapsulation efficiency percentage suggests how much $A$. goniocephala $\mathrm{F}$ and $\mathrm{H}$ extracts coated in chitosan NP. The percentage of the encapsulated extract into chitosan NP was determined and the results were given in Table 3. As shown in Table 3, the percentage was found $77.6 \%$ and $10.2 \%$ for $F$ and $\mathrm{H}$ fractions, respectively. This showed that as much as 77.6 or $10.2 \%$ of the fractions are successfully encapsulated by chitosan NPs. Also loading capacity (LC) in NPs was found as 7.76 and $1.39 \%$ for $\mathrm{F}$ and $\mathrm{H}$ fractions, respectively. According to the total phenolic method, the encapsulation efficiency percentages were $64.37 \%$ for the $F$ extract and $14.84 \%$ for the $\mathrm{H}$ extract.

Table 3. Encapsulation efficiency and loading capacity of the NPs

\begin{tabular}{lll}
\hline Parameter & F extract & H extract \\
\hline Linear equation & $y=0.2808 x+0.02339$ & $y=0.4667 x-0.002409$ \\
\hline Slope $\pm S D$ & $0.2808 \pm 0.02$ & $0.4667 \pm 0.01$ \\
\hline Intercept $\pm S D$ & $0.0234 \pm 0.0011$ & $0.002409 \pm 0.0007$ \\
$r$ & 0.9921 & 0.9925 \\
\hline EE \% & $77.60 \pm 0.04$ & $10.20 \pm 0.02$ \\
LC \% & $7.76 \pm 0.01$ & $1.39 \pm 0.07$ \\
\hline TPC* & $0.0174 \pm 0.0005$ & $0.0566 \pm 0.0010$ \\
NP & $0.0112 \pm 0.0003$ & $0.0084 \pm 0.0003$ \\
EE \% (TPC) & $64.37 \pm 0.06$ & $14.84 \pm 0.11$ \\
\hline
\end{tabular}

* TPC: Total phenolic contents (mg gallic acid equivalent / mg extract), Nanoparticles: NPS.

\subsection{Cytotoxicity results of extracts, fractions, and NPs}

Cancer is the second most common cause of death globally, despite the use of many treatment methods (21). Crucial side effects caused by conventional drugs used for chemotherapy affect patients negatively. Current studies have focused on natural herbal remedies, which are more advantageous than conventional cancer drugs and have anticancer effects $(22,23)$. The cytotoxic activities of chloroform extracts from the plant on MCF-7 and HT-29 cell lines were examined, and results were shown in Figure 2 and 3 . Results indicated that $\mathrm{F}$ and $\mathrm{H}$ extracts possessed more cytotoxic activity on both MCF-7 and HT-29 cell lines compared to other chloroform extracts. On MCF-7 cell line, the cell viability ranged between $51.691 \pm 0.566 \%$ and $85.019 \pm 0.637 \%$ (Figure 2). According to the results $F$ and $\mathrm{N}$ samples of the extracts of plant showed the highest and lowest cytotoxic effect on MCF-7 cell line, respectively. In addition, $\mathrm{H}$ samples showed high cytotoxic activity on MCF-7 cell line (57.502 $\pm 0.904 \%)$. 


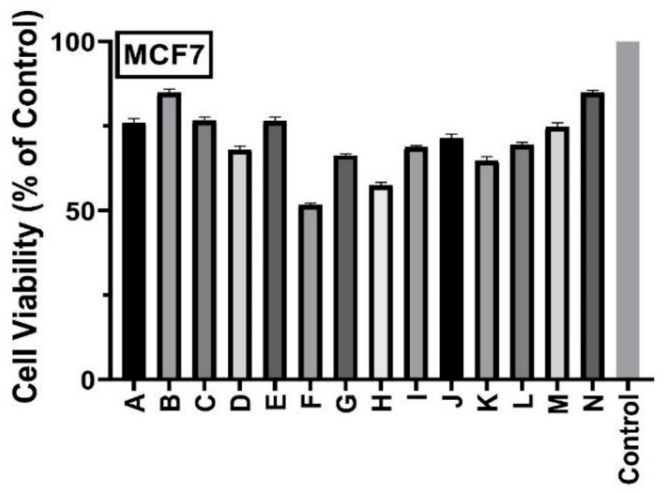

Samples

Figure 2. Cell viability results of chloroform extracts of the plant. Cells were treated with samples at a concentration $50 \mu \mathrm{g} / \mathrm{mL}$. Cell viability of the control group was determined as $100 \%$.

On HT-29 cell line, the cell viability was between $49.368 \pm 0.569$ $\%$ and $82.642 \pm 0.593 \%$ (Figure 3 ). According to the results $\mathrm{F}$ and $\mathrm{N}$ samples of the plant extracts showed the highest and lowest cytotoxic effect on HT-29 cell line respectively. In addition, $\mathrm{H}$ samples showed high cytotoxic activity on HT-29 cell line $(57.502 \pm 0.904 \%)$. In parallel with the cell viability results of MCF-7 cells, the highest cytotoxic effect was observed in $\mathrm{F}$ and $\mathrm{H}$ samples in $\mathrm{HT}-29$ cells where all extracts were applied separately (F: $54.504 \pm 0.574 \%$ and $\mathrm{H}$ : $49.368 \pm 0.569 \%)$. Moreover, $\mathrm{N}$ samples showed the least cytotoxic activity (82.642 $\pm 0.593 \%)$.

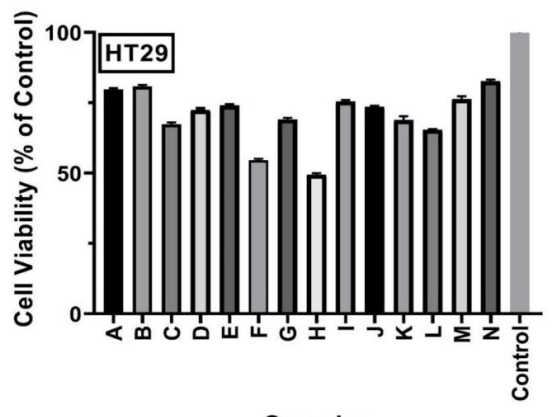

Samples

Figure 3. Cell viability results of chloroform extract of the plant. Cells were treated with samples at a concentration $50 \mu \mathrm{g} / \mathrm{mL}$

When we evaluated the cytotoxic effects of the extracts on MCF-7 and HT-29 cells, it was observed that $\mathrm{F}$ and $\mathrm{H}$ chloroform extracts had stronger cytotoxic potential. Based on these results, NPs containing $\mathrm{F}$ and $\mathrm{H}$ extracts were prepared, and the extracts and NPs containing the extracts were treated with MCF-7 and HT-29 cells at different concentrations. These concentrations were determined to be l:12.5 $\mathrm{\mu g} /$ $\mathrm{mL}$, II: $25 \mu \mathrm{g} / \mathrm{mL}$, III: $50 \mu \mathrm{g} / \mathrm{mL}$, and IV: $100 \mu \mathrm{g} / \mathrm{mL}$. XTT cell viability test was performed in both cell lines at determined concentrations and $I_{50}$ values were evaluated. When we evaluate the results in Figure 4, the NPs containing the same concentration of extract showed a higher cytotoxic effect in MCF-7 cancer cells compared to the samples containing the extract. In cells treated with different concentrations (I, II, III, and IV) of F extract, the viability of MCF-7 cells was between $76.068 \pm 1.704 \%$ and $38.586 \pm 0.881 \%$. In addition, cells treated with NPs including same concentrations (I, II, III, and IV) of F extract, the viability of MCF-7 cells was between $65.185 \pm 0.976 \%$ and $32.110 \pm 1.747 \%$. In cells treated with different concentrations of $\mathrm{H}$ extract, the viability of MCF-7 cells was between $79.997 \pm 0.658 \%$ and $40.918 \pm 0.294 \%$. Moreover, cells treated with NPs including same concentrations of H extract, the viability of MCF-7 cells was between $68.548 \pm 1.216 \%$ and $35.726 \pm 0.655 \%$. According to the results of the XTT cell viability assay, it can be said that depending on the concentration of the extracts applied, it has a higher cytotoxic effect and anticancer effect in MCF-7 cells. $\mathrm{IC}_{50}$ values of $\mathrm{F}$ extract and NP loading with $\mathrm{F}$ extract were calculated as $56.780 \mu \mathrm{g}$ and $40.860 \mu \mathrm{g}$, respectively, on MCF-7 cells. In addition, $\mathrm{IC}_{50}$ values of $\mathrm{H}$ extract and NP containing $\mathrm{H}$ extract were calculated as $61.630 \mu \mathrm{g}$ and 44.524 $\mu \mathrm{g}$, consecutively, on MCF-7 cells. FI NP (32.110 $\pm 1.747 \%)$ and HI NP (35.726 $\pm 0.655 \%)$ NP samples indicated the highest cytotoxic effect on MCF-7 cell line. NPs including extracts had lower IC $\mathrm{C}_{50}$ values than extracts on MCF7 - cell line (Figure 4).

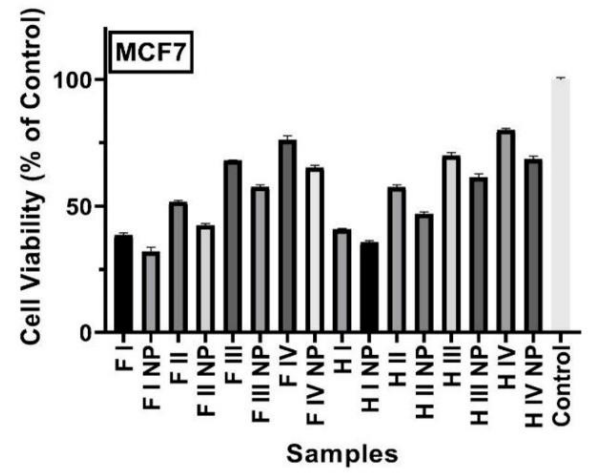

Figure 4. Cell viability results of $F$ and $H$ chloroform extract and NPS. MCF-7 cells were treated with samples at determined concentration (I:12.5 $\mu \mathrm{g} / \mathrm{mL}$, II: $25 \mu \mathrm{g} / \mathrm{mL}$, III: $50 \mu \mathrm{g} / \mathrm{mL}$, and IV: $100 \mu \mathrm{g} / \mathrm{mL}$ ). Cell viability of the control group was determined as $100 \%$.

According to the results of Figure 5, the NPs including the plant extract had a greater cytotoxic activity in HT29 cancer cells compared to the samples containing the extract. In cells treated with different concentrations (I, II, III, and IV) of F extract, the cell viability of HT-29 cells was between $80.408 \pm 0.825 \%$ and $43.596 \pm 0.882 \%$. In addition, cells treated with NPs containing same concentrations (I, II, III, and IV) of F extract, the cell viability of HT-29 cells was between $66.521 \pm 0.976 \%$ and $35.440 \pm 1.221 \%$. In cells treated with predetermined concentrations of $\mathrm{H}$ extract, the cell viability of HT-29 cells was between $77.237 \pm 1.155 \%$ and $42.580 \pm 0.761 \%$. Moreover, cells treated with NPs including same concentrations of $\mathrm{H}$ extract, the viability of HT-29 cells was between $69.552 \pm 0.891 \%$ and $31.560 \pm 0.642 \%$. According to the results, IC $\mathrm{IC}_{50}$ values of $\mathrm{F}$ extract and NP containing $F$ extract were calculated as $64.460 \mu \mathrm{g}$ and $45.482 \mu \mathrm{g}$, respectively, on HT-29 cells. Moreover, IC 
values of $\mathrm{H}$ extract and NP loading with $\mathrm{H}$ extract were calculated as $51.280 \mu \mathrm{g}$ and $40.860 \mu \mathrm{g}$, consecutively, on HT-29 cells. In addition, FI NP (35.440 $11.222 \%)$ and HI NP $(31.560 \pm 0.642 \%)$ NP samples showed the highest cytotoxic effect on HT-29 cell line (Figure 5).

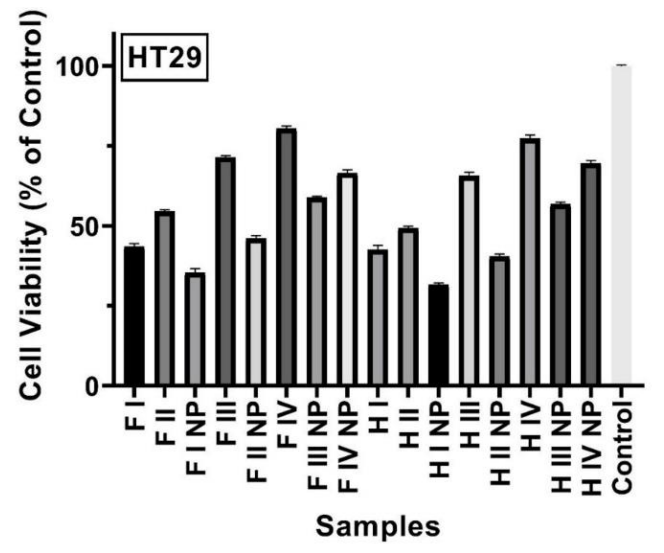

Figure 5. Cell viability results of $F$ and $H$ chloroform extract and nanoparticles. HT-29 cells were treated with samples at determined concentration (I: $12.5 \mu \mathrm{g} / \mathrm{mL}$, II: $25 \mu \mathrm{g} / \mathrm{mL}$, III: $50 \mu \mathrm{g} / \mathrm{mL}$, and IV: 100 $\mu \mathrm{g} / \mathrm{mL}$ ). Cell viability of the control group was determined as $100 \%$

\section{DISCUSSION}

Results showed that chitosan NPs including extracts had lower IC I0 $_{50}$ values than only extracts. In a study, it was proved that $C$. casia extract, which is widely used for antihypercholesterol in Indonesia, can be encapsulated with chitosan NPs and this NP has a cholesterol-lowering effect (19). In another study, chitosan NPs of anticancer effective elagic acid were created. It has been observed that the encapsulated elagic acid gives a lower $I C_{50}$ value for oral cancer treatment compared to pure elagic acid (24). In a study, gelatin-based NPs of anticancer-effective, tannic acid, curcumin, theaflavin and epigallocatechin gallate polyphenols were prepared, and among these molecules, it was found that both free and nanocapsulated forms of epigallocatechin gallate were effective in breast cancer (25). In a study, the efficiency and release of the encapsulation potential of catechins was investigated and for this purpose, it was found that more stable results were obtained in in vitro and in vivo studies with chitosan NPs that they created by adding reducing substances to catechins (26). In a study, PGA-based NP was produced with the double emulsion technique of curcumin. They proved that the drug release rate of the NP was shorter without hydrolytic degradation in the presence of curcumin (27). In another study, NPs loaded with antioxidant hydroxytyrosol, and hydrocortisone were produced. As a result of the study, it was reported that this dual NP structure has an antioxidant and anti-inflammatory effect in the treatment of percutaneous atopic dermatitis (28). In a review study, studies in which nanoencapsulated polyphenols were produced to eliminate the negativities such as weak bioavailability in the therapeutic applications of polyphenols were compiled. As a result of this review, they stated that polyphenols are more effective than their therapeutically pure forms, such as determining their release in nanoencapsulated form, extending the shelf life of active ingredients (29). There is another review in the literature based on the investigation of biopharmaceutical properties of extracts obtained from plants according to lipid and polymer-based NPs. As a result of this review, it was concluded that due to the controlled kinetic release of NPs produced using plant extracts, the effect of increasing the effect against microorganisms such as antioxidants and parasites is increased (30). They found that the $I C_{50}$ value of green tea decreased after the nanoencapsulation created with chitosan, thus increasing the antioxidant effect (31). In another study, they found that a very small dose of $P$. dactylifera loaded chitosan NPs prevented the toxicity of doxorubicin by the development of antioxidant enzymes (32). Biosynthesized AgNPs were found to show a higher antioxidant and antibacterial activity compared to Prosopis farcta fruit extract alone (33). Similarly, in our study, chitosan NPs containing the most active extracts were prepared and characterization studies were carried out. In cell culture studies, the anti-proliferative and anticancer effects of the extracts embedded in chitosan, a carrier system, were evaluated. IC $C_{50}$ values calculated according to XTT cell viability results explain that NPs containing $\mathrm{F}$ and $\mathrm{H}$ chloroform extracts of $A$. goniocephala have desirable high anticancer activity.

Encapsulation efficiency is a measure of the ability of the carrier system used to embed the active substance. The encapsulation efficiency of the active substances in the formulations is crucial in terms of bioactivity and pharmacokinetic efficiency. Therefore, for the prepared formulations to show the desired effectiveness in practice, the encapsulation efficiency should be above a certain value. In our study, while the encapsulation efficiency of the F extract was $77.6 \%$, this value was $10.2 \%$ in the $\mathrm{H}$ extract. When the encapsulation efficiency results were examined, it was observed that especially the F extract was successfully encapsulated by ionic gelation method.

\section{CONCLUSION}

According to the results of the XTT cytotoxicity and all the antioxidant assays study, among 14 extracts, $F$ and $\mathrm{H}$ chloroform extracts of $A$. goniocephala showed better antioxidant and cytotoxic activity. While antioxidant activity results of chitosan NPs were close to unencapsulated extracts, cytotoxic activity results were found to be better than unencapsulated extracts. Based on these findings, it is anticipated that using the encapsulated forms of $A$. goniocephala rather than the raw extract of the plant in the treatment would be more successful.

Acknowledgments: We would like to thank the Scientific and Technological Research Council of Turkey (TÜBITAK) for the 
financial support of this research (Project No: 116S509) and Serkan Köstekci for help during the field studies.

\section{REFERENCES}

[1] Donna SS, Robert DK. Introduction to cancer chemotherapeutics. Chem Rev 2009;109(7):2859-2861.

[2] ShailiE.Platinum anticancer drugs and photochemotherapeutic agents: recent advances and future developments. Sci Prog 2014;97(1):20-40.

[3] Karamenderes C, Apaydin Ş. Antispasmodic effect of Achillea nobilis L. subsp. sipylea (O. Schwarz) Bassier on the rat isolated duodenum. J Ethnopharmacol 2003;84(2-3):175179

[4] Turkoglu i, Turkoglu S, Celik S, Kahyaoglu M. Antioxidant and antimicrobial activities of Turkish endemic Achillea species. African J Microbiol Res 2010;4(19):2034-2042.

[5] Moradkhani S, Ayatollahi AM, Ghanadian M, Moin MR, Razavizadeh M, Shahlaei M. Phytochemical analysis and metalchelation activity of Achillea tenuifolia Lam. Iran J Pharm Res 2012;11(1):177-183.

[6] Applequist WL, Moerman DE. Yarrow (Achillea millefoliumL.): A Neglected panacea A review of ethnobotany, bioactivity, and biomedical research. Econ Bot 2011;65(2):209-225.

[7] Tanker, N., Koyuncu, M, Çoşkun, M. (2007). Ankara Univ. Faculty of Pharmacy Publications, 93, 313-319. Tanker N, Koyuncu M, Çoşkun M. Ankara Univ. Faculty of Pharmacy Publications, Ders Kitapları, Ankara Üniversitesi Basımevi, Ankara, 2007; 93:313-319 (Turkish).

[8] Baser KHC, Demirci B, Duman H, Aytaç Z, Adigüzel N. Composition of the essential oil of Achillea goniocephala Boiss. et Bal. from Turkey. J Essent Oil Res 2001;13(4):219220.

[9] Yener I, Yilmaz MA, Olmez OT, Akdeniz M, Tekin F, Hasimi $\mathrm{N}$, Alkan $\mathrm{MH}$, Ozturk $\mathrm{M}$, Ertas A. A detailed biological and chemical investigation of sixteen Achillea species' essential oils via chemometric approach. Chem Biodivers 2020;17(3):e1900484.

[10] Yoksan R, Jirawutthiwongchai J, Arpo K. Encapsulation of ascorbyl palmitate in chitosan nanoparticles by oil-in-water emulsion and ionic gelation processes. Colloids and Surfaces B: Biointerfaces 2010;76(1): 292-297.

[11] Wang S, Su R, Nie S, Sun M, Zhang J, Wu D, Moustaid-Moussa NJ. Application of nanotechnology in improving bioavailability and bioactivity of diet-derived phytochemicals. J Nutr Biochem 2014; 25(4):363-376.

[12] Alver E. Investigation Removal Effectiveness of Anionic Dyes via Encapsulation in Chitosan Nanoparticles Prepared by Ionotropic Gelation Method and the Dye Storage Performance in Nanoparticles. Gümüşhane University Journal of Science and Technology Institute 2018;8(1):26-37.

[13] Benzie IF, Strain JJ, The ferric reducing ability of plasma (FRAP) as a measure of "antioxidant power": the FRAP assay. Anal Biochem 1996; 239(1):70-76.

[14] Fu W, Chen J, Cai Y, Lei Y, Chen L, Pei L, Zhou D, Liang X, Ruan JJ. Antioxidant, free radical scavenging, antiinflammatory and hepatoprotective potential of the extract from Parathelypteris nipponica (Franch.et Sav.) Ching. J Ethnopharmaco 2010;130(3):521-528.

[15] Apak R, Güclü K, Ozyurek M, Karademir SE. Novel total antioxidant capacity index for dietary polyphenols and vitamins $\mathrm{C}$ and $\mathrm{E}$, using their cupric ion reducing capability in the presence of neocuproine: CUPRAC Method. J Agric Food Chem 2004;52(26): 7970-7981.

[16] Wolf N, Kuchler S, Radowski MR, Blaschke T, Kramer KD, Weindi G. Influences of opioids and nanoparticles on in vitro wound healing models. Eur J Pharm Biopharm 2009;73(1):34-42.

[17] Calvo P, Remunan-Lopez C, Vila-Jato JL, Alonso MJ. Novel hydrophilic chitosan-polyethylene oxide nanoparticles as protein carriers. J Appl Polym Sci 1997;63(1):125-132.

[18] Wikanta T, Erizal T, Tjahyono T, Sugiyono T. Synthesis of polyvinyl alcohol-chitosan hydrogel and study of its swelling and antibacterial properties. Squalen Bulletin of Marine and Fisheries Postharvest and Biotechnology 2012;7(1):1-10.

[19] Purbowatiningrum N, Ismiyarto EF. Cinnamomum casia Extract Encapsulated Nanochitosan as Antihypercholesterol. IOP Conf Ser: Mater Sci Eng 2017;172:012035.

[20] Han HJ, Lee JS, Park SA, Ahn JB, Lee HG. Extraction optimization and nanoencapsulation of jujube pulp and seed for enhancing antioxidant activity. Colloids and Surfaces B: Biointerfaces 2015;130:93-100.

[21] Pucci C, Martinelli C, Ciofani G. Innovative approaches for cancer treatment: Current perspectives and new challenges. Ecancermedicalscience 2019;13:961.

[22] Chikara S, Nagaprashantha LD, Singhal J, Horne D, Awasthi S, Singhal SS. Oxidative stress, and dietary phytochemicals: Role in cancer chemoprevention and treatment. Cancer Lett 2018;413:122-134.

[23] Singh S, Sharma B, Kanwar SS, Kumar A. Lead phytochemicals for anticancer drug development. Front Plant Sci 2016;7:8973.

[24] Arulmozhi V, Pandian K, Mirunalini S. Ellagic acid encapsulated chitosan nanoparticles for drug delivery system in human oral cancer cell line (KB). Colloids and Surfaces B: Biointerfaces 2013;110:313-320.

[25] Shutava TG, Balkundi SS, Vangala P, Steffan JJ, Bigelow RL, Cardelli JA, O'Neal DP, Lvov YM. Layer-by-layer-coated gelatin nanoparticles as a vehicle for delivery of natural polyphenols. ACS Nano 2009;3(7):1877-1885.

[26] Dube A, Ng K, Nicolazzo JA, Larson I. Effective use of reducing agents and nanoparticle encapsulation in stabilizing catechins in alkaline solution. Food Chem 2010;122(3):662-667.

[27] Mayol L, Serri C, Menale C, Crispi S, Piccolo MT, Mita L, Giarra S, Forte M, Saija A, Biondi M, Mita DG. Curcumin loaded PLGA-poloxamer blend nanoparticles induce cell cycle arrest in mesothelioma cells. Eur J Pharm Biopharm 2015;93:37-45.

[28] Hussain Z, Katas H, Amin MCIM, Kumolosasi E, Buang F, Sahudin S. Self-assembled polymeric nanoparticles for percutaneous co-delivery of hydrocortisone/hydroxytyrosol: an ex vivo and in vivo study using an NC/Nga mouse model. Int J Pharm 2013;444(1-2):109-119.

[29] Conte R, Calarco A, Napoletano A, Valentino A, Margarucci S, Di Cristo F, Di Salle A, Peluso GJ. Polyphenols nanoencapsulation for therapeutic applications. J Biomole Res Ther 2016;5(2):1000139.

[30] Zorzi GK, Carvalho ELS, von Poser GL, Teixeira HF. On the use of nanotechnology-based strategies for association of complex matrices from plant extracts. Revista Brasileira de Farmacognosia 2015;25:426-436.

[31] Piran F, Khoshkhoo Z, Hosseini SE, Azizi MH. Controlling the Antioxidant Activity of Green Tea Extract through Encapsulation in Chitosan-Citrate Nanogel. J Food Qual 2020:7935420. 
[32] Sahyon HA, Al-Harbi SA. Antimicrobial, anticancer and antioxidant activities of nano-heart of Phoenix dactylifera tree extract loaded chitosan nanoparticles: In vitro and in vivo study. Int J Biol Macromol 2020;(160):1230-1241.
[33] Salaria S, Bahabadi SE, Samzadeh-Kermani A, Yosefzaei F. Invitro Evaluation of Antioxidant and Antibacterial Potential of Green Synthesized Silver Nanoparticles Using Prosopis farcta Fruit Extract. Iran J Pharm Res 2019;18(1):430-445.

How to cite this article: Taskin D, Dogan M, Ermanoglu M, Arabaci T. Achillea goniocephala Extract Loaded into Nanochitosan: In Vitro Cytotoxic and Antioxidant Activity. Clin Exp Health Sci 2021; 11: 659-666. DOI: 10.33808/clinexphealthsci.972180 